\title{
Regeneration of Brownfield Land: the Environmental Law Challenges
}

\begin{abstract}
Purpose - The aim of the project was to investigate environmental law issues surrounding the regeneration of brownfield land.

Methodology - Following a literature review, an inductive approach and an interpretivist epistemology with a phenomenological focus were chosen. A constructionist ontological stance was adopted. A qualitative paradigm was selected to explore the issues in a focus group comprising industry, legal expert and academic contributors.
\end{abstract}

Findings - A critique of the literature on relevant environmental law issues including contaminated land, waste management, water pollution, environmental impact assessment issues and finally the political agenda. Contaminated land, waste management, regulators and legislation were discussed in the focus group. The participants contributed their experiences and proposed several changes to environmental law. However, water pollution and environmental impact assessments were not considered by the contributors.

Implications - Developers face many environmental law challenges when endeavouring to progress housing on brownfield sites including contaminated land, funding, waste treatment permits, water pollution and environmental impact assessments. The benefits of the remediation of brownfield sites for housing seem to be a political priority, but reform of challenging environmental law issues less so. Understandably, the legal complexities of Brexit will take precedence.

Value - The literature review identified the need to research the experience of brownfield environmental law challenges and recommended changes to environmental law from industry, legal experts and academia.

\section{Research paper}

Key words - Brexit, brownfield land, contaminated land, environmental law, housing, legislation, political context, reform, regulators and waste management.

\section{Introduction}

The aim of the project was to investigate environmental law issues surrounding the regeneration and re-use of brownfield land. This paper examines the environmental law challenges to the regeneration of brownfield land. The introduction sets the issues within the political context. There is a focus on housing in the United Kingdom's West Midlands region | but, the issues are applicable to other developments-across the country in England and Wales.

The second section analyses contaminated land challenges including the legal regime, case law, remediation declarations, critique of the legal system, the Environmental Liability Directive liability for contaminated land and funding. The third section examines other environmental law issues including waste management, water pollution and environmental impact assessments. The fourth section explores the political agenda including priorities in the West Midlands, Brexit implications, better regulation and the priority of environmental 
law reform. The fifth section details the research methodology. with tThe focus group results are and discussion in the sixth section and their analysis in the seventh section. Finally, conclusions are presented.

\subsection{Political context}

Wong and Schulze-Baing (2010) explain that the reuse of brownfield land for housing has been a major policy objective in England since the late 1990s. They concluded that this re-use helps improve income and employment prospects for the most deprived areas in Britain.

In January 2015, the Department for Communities and Local Government (2015) published their consultation proposals for building more homes on brownfield land. The consultation (p.9) explained that 'Brownfield' (previously developed) land is defined in Annex 2 of the National Planning Policy Framework as: "Land which is or was occupied by a permanent structure, including the curtilage of the developed land (although it should not be assumed that the whole of the curtilage should be developed) and any associated fixed surface infrastructure." The Campaign to Protect Rural England (2016) argued that brownfield sites across England can provide at least 1.1 million new homes.

The Chancellor (2016), in his Autumn Statement (23 November 2016), announced £2.3 billion for a new Housing Infrastructure Fund. "The fund will be used for projects such as roads and water connections that will support the construction of up to 100,000 new homes in the areas where they are needed most. On top of that, $£ 1.4$ billion will be used to provide 40,000 new affordable homes, including some for shared ownership and some for affordable rent. And another $£ 1.7$ billion will be used to speed up the construction of new homes on public sector land."

The Housing and Planning Minister (2017), Gavin Barwell, confirmed on 3 April 2017 that Councils will have new tools to speed up development of derelict and underused land for new homes. He explained that local authorities will now have to produce and maintain up-todate, publicly available registers of brownfield sites available for housing locally. He added that the $£ 3$ billion Home Builders Fund will be used to support the development of brownfield sites, with an additional $£ 1.2$ billion provided to unlock at least 30,000 Starter Homes on brownfield land. There is therefore a national political focus on developing housing on brownfield land.

\section{Contaminated Land}

This section explains the contaminated land legal regime illustrated by case law and remediation declarations. The system is then critiqued and the liability for remediating contaminated land debated. requirements of the environmental liability directive outlined. The funding implications are then explored.

\subsection{Legal regime}

The purpose of Part 2A of the Environmental Protection Act $1990^{1}$ (EPA 1990) is to identify | and remediate contaminated land in England, Wales and Scotland which poses an

\footnotetext{
${ }^{1}$ Environmental Protection Act 1990, c.43.
} 
unacceptable risk to human health or the environment which is not being remediated voluntarily. Contaminated land is defined by section 78A(2) as:

"any land which appears to the local authority in whose area it is situated to be in such a condition, by reason of substances in, on or under the land, that-

(a) significant harm is being caused or there is a significant possibility of such harm being caused; or

(b) pollution of controlled waters is being, or is likely to be, caused"

The person primarily liable for the remediation costs is the "polluter" (Class A person) with the owner or occupier (Class B person) secondarily liable. Statutory successors will also take on the liabilities of their predecessor entities (Lowther, 2006). As Lees (2016, p. 12)

explained, "The [secondary] liability is justified not by fault or causation, but by a direct relationship with the land. The guidance on the contaminated land provisions in the UK demonstrates that the primary objectives of the regime are not to ensure that the polluter who caused damage is made to pay for that damage, but rather that the damage is remediated."

Under the statutory guidance, local authorities were required to devise and then implement an inspection strategy but no deadline was imposed. Therefore, local authorities have made slow progress inspecting their areas resulting in a lack of data on the extent of contaminated land in England and Wales (Fogleman, 2014a). Nevertheless, Part 2A imposes a duty on a local authority to serve a remediation notice on an appropriate person if the authority decides that land is contaminated (Fogleman, 2014b). Failure to comply with a remediation notice is a criminal offence. A developer who purchases brownfield land runs the risk of the local authority subsequently serving a remediation notice on them as a Class B person. Their potential liability is uncapped and failure to comply could result in a criminal conviction.

\subsection{Case law}

Developers have indeed been served remediation notices as illustrated by the following cases concerning Circular Facilities (London) Ltd and Crest Nicholson Residential Ltd. The liability of National Grid Gas plc and Powys County Council for contaminated land following statutory transfer schemes are also considered.

\section{Circular Facilities}

Circular Facilities (London) Ltd (CFL) built a residential estate on a site which was discovered by Sevenoaks District Council (SDC) to be causing significant risk of harm to the residents from significant levels of methane and carbon dioxide seeping from pits filled with now decomposing organic material. In 2002, SDC served a remediation notice on CFL as a class A appropriate person (Brown, 2016). In Circular Facilities (London) Ltd v Sevenoakes District Council ${ }^{2}$, CFL appealed against the remediation notice. The case was confidentially settled out of court and the notice was revoked.

\section{$\underline{\text { St Leonard's Court }}$}

St Leonard's Court is a residential estate near St Albans, Hertfordshire. The site was previously a chemical works which was purchased by a developer. Bromate and bromide was discovered by St Albans District Council to have leached into the soil contaminating the water source. The Environment Agency served remediation notices on both the former chemical works operator and the developer.

\footnotetext{
${ }^{2}$ Circular Facilities (London) v Sevenoakes District Council [2005] EWGC 865 (Admin).
} 
In $R$ (Redland Minerals Ltd) v Secretary of State for Environment, Food and Rural Affairs ${ }^{3}$, the judge concluded "not only that a manufacturer of chemicals had caused chemical contaminants to enter soil and groundwater, but that a developer that subsequently removed buildings and hardstandings from the site during its re-development for housing, had caused the chemicals to enter the groundwater due to rain falling directly on the ground and accelerating the entry of contaminants to lower levels in the ground" (Fogleman, 2014b, p.50). The related case was $R$ (Crest Nicholson Residential Ltd) $v$ Secretary of State for Environment, Food and Rural Affairs ${ }^{4}$. The judge found both parties liable and apportioned liability between them.

National Grid Gas plc

In 2001, residents of land near Bawtry, Doncaster discovered a pit with a tar-like substance in their back gardens which proved to be a by-product of gas making processes. The site was subsequently determined to be contaminated land. The site had been a gas works operated by statutory predecessors to National Grid Gas plc (NGG) from approximately 1915 and later developed for housing in the 1960s.

In $R$ (on the application of National Grid Gas plc formerly Transco plc) v Environment Agency $^{5}$, the House of Lords considered whether liability for remediation could be transferred notwithstanding the fact that liability was created after statutes which transferred liability from statutory predecessors. It was held that NGG had not itself caused or knowingly permitted the presence of the contamination as it had only come into existence 20 years after the site had been sold for housing and a deemed past liability had not been created by the EPA 1990 for the acts of the predecessor.

Powys County Council

In Powys County Council v Price ${ }^{6}$, the Court of Appeal considered whether Powys County Council (PCC) could be defined as an "appropriate person" under the EPA 1990 by virtue of operation of a statutory transfer scheme. The Respondents were owners of a farm in Powys, Wales where from 1960 until 1993 the predecessors of PCC had operated a landfill site on part of the farm. Environmental monitoring undertaken by PCC led to concerns about water pollution from leachate from the site. Compelled by the reasoning in the above NGG case,

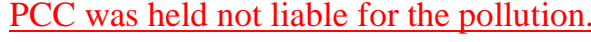

\section{$\underline{2.3 \text { Remediation declarations }}$}

Fogleman (2014a) detailed the following remediation declarations:

- Warrington Borough Council, in 2008, issued a remediation declaration for the pollution of shallow groundwater and a nearby brook (controlled waters).

- Congleton Borough Council, in 2011, decided that Malkins Bank Golf Course was contaminated land. However, the Council simultaneously issued a remediation declaration stating that it would be disproportionate to remediate the site because

${ }^{3} R$ (Redland Minerals Ltd) v Secretary of State for Environment, Food and Rural Affairs [2010] EWHC 913 (Admin).

${ }^{4} R$ (Crest Nicholson Residential Ltd) v Secretary of State for Environment, Food and Rural Affairs [2010] EWHC 1561 (Admin).

${ }^{5} R$ (on the application of National Grid Gas plc formerly Transco plc) v Environment Agency [2007]UKHL 30 6 Powys County Council v Price [2017] EWCA Civ 1133

\section{Formatted: Underline}

Formatted: Font: Italic

Formatted: Font: Italic

Formatted: Underline

Formatted: Font: Italic

Formatted: Font: Italic

Formatted: Font: (Default) Times New Roman

Formatted: Font: (Default) Times New Roman

Formatted: Font: (Default) Times New Roman 
groundwater pollution was having limited impact on the quality of nearby surface waters.

- Cornwall County Council, in 2011, issued remediation declaration for a former gasworks site where pollutants were entering the Fal Estuary through the harbour wall.

$\underline{\text { She complains that no figures are available for the total number of remediation declarations. }}$

\section{$2.3 \underline{3}$ Critique of the legal system}

Brown (2016) argued that Circular Facilities (London) v Sevenoakes District Council ${ }^{7}$ illustrates the inadequacy of the contaminated land regime. Firstly, developers may be discouraged from developing contaminated land due to the risk of introducing pathways and receptors during construction. Secondly, local authorities are concerned about the expense of possible appeals to remediation notices including legal fees and funding the remediation costs themselves.

Property developers may have to bear the burden of Class A liability where polluters have statutory successors. When analysing potential liability regarding corporate succession, the primary factor would be the distinction between a share purchase or an asset or business sale.

Fogleman (2014b) argues that Part 2A of the EPA 1990 is unfit for purpose. She found that (p.43) “the introduction of a contaminated land regime that delegates primary implementation and enforcement authority to local authorities, and that severely limits their discretion in doing so, has resulted in a regime that has proven to be unworkable in practice and that has failed to meet its objectives."

\section{| $2.4 \underline{4}$ Environmental Liability Directive Liability for remediating contaminated land}

The contaminated land legal regime does not derive from the European Union. Nevertheless, the Environmental Liability Directive ${ }^{8}$ (ELD) aims to create a framework of environmental liability, based on the "polluter pays" principle, to prevent and remedy environmental damage. The ELD defines environmental damage as: damage that significantly affects the environmental (ecological, chemical or quantitative) status of water resources; damage to land creating a significant risk to human health; damage to protected species and natural habitats that adversely affects conservation (EUR-Lex, 2016).The ELD does not impose remediation liability on the owner or occupier of land who did not cause or permit the contamination. However, the ELD does allow Member States to maintain or adopt more draconian provisions (Lees, 2016).

Lees (2016, p.7) identified five models of liability offor remediating contaminated land:

1. The polluter should pay and no one else should pay. If the polluter cannot be found, there will be no liability for remediation.

\footnotetext{
${ }^{7}$ Circular Facilities (London) v Sevenoakes District Council [2005] EWGC 865 (Admin)

${ }^{8}$ Council Directive (EC) (2004), “35 on environmental liability with regard to the prevention and remedying of environmental damage".
} 
2. As a priority, the polluter should pay, but where the polluter is not found, it may be possible for residual liability to rest elsewhere on, for example, owners or occupiers of the land or the State.

3. As a priority, the right sort of polluter should pay, but if the polluter does not meet those criteria (eg. fault), then others may also be liable. Causation is not the only test for being a polluter.

4. Liability is based primarily on fault, not causation.

5. The polluter may be liable, but so equally may others be, regardless of fault.

The United Kingdom together with Austria, Bulgaria, Estonia, Finland, France, Hungary, Romania, Slovakia, Spain and Sweden has adopted the model 2 approach. However, an opportunity has arisen to evaluate this choice and perhaps consider different frameworks.

\section{5므 Funding}

Brown (2016, p. 211) argued that "Public sector incentives have been cut so significantly that the potential uptake of contaminated sites by private sector developers is likely to decrease." The introductory section identifies potential sources of public sector funds but access to them seems unlikely to be straightforward. Fogleman (2014b) identified a key issue that remediation costs can exceed the current value of the land itself.

\section{Environmental Law Issues}

Waste management, water pollution and environmental impact assessment issues are explored in this section.

\subsection{Waste management}

The Environmental Permitting (England and Wales) Regulations (20160) ${ }^{9}$ (EPR) require those carrying on certain types of activity to hold an environmental permit.derive from the Waste Framework Directive ${ }^{1 \theta}$ - In England and Wales, a waste treatment activity on a site requires a permit from the Environment Agency or-Local Authority Natural Resources Wales.

Operations on brownfield sites may be considered to be waste treatment and have been subject to judicial scrutiny. In Kent County Council v Queenborough Rolling Mill Co Ltd ${ }^{11}$, an area subject to subsidence was filled with a mixture of ballast, china, china clay and broken pottery which was deemed to be waste when it was removed from the original site and its character was not subsequently changed either by its being sorted into different categories or by its usefulness for infill purposes. By contrast, in Cheshire County Council v Armstrong's Transport (Wigan) Ltd ${ }^{12}$, building site rubble which was crushed and returned to the original site to assist in rebuilding works was found not to be waste because it was not discarded but merely removed, processed and returned. Thus, construction operations on brownfield sites may require a waste treatment permit.

\footnotetext{
${ }^{9}$ Environmental Permitting (England and Wales) Regulations (20160), SI 20160/6751154, r.12.

${ }^{10}$ Council Directive (EC) 2006, "12 on waste".

${ }^{11}$ Kent County Council v Queenborough Rolling Mill Co Ltd [1990] 154 J.P. 530.

${ }^{12}$ Cheshire County Council v Armstrong's Transport (Wigan) Ltd [1995] Env. LR 62.
} 


\subsection{Water pollution}

Regulation 12 of the EPR also states that a person cannot cause or knowingly permit a water discharge activity except under and to the extent authorised by an environmental permit. Contravention is an offence under regulation 38.

The Water Resources Act $1991^{13}$ aims to prevent and minimise water pollution and is enforced by the Environment Agency. Under the Act, it is an offence to cause or knowingly permit any poisonous, noxious or polluting material, or any solid waste to enter any controlled water. Silt and soil are included in the definition of polluting material. If soil is found to be polluting a water body or watercourse, the Environment A gency may prevent or clear up the pollution, and recover the damages from the landowner or responsible person (Department for Environment Food and Rural Affairs, 2017).

Many of the remediation declarations have concerned water pollution (Fogleman, 2014a):

- Warrington Borough Council, in 2008, issued a remediation declaration for the pollution of shallow ground water and a nearby brook (controlled waters).

- Congleton Borough Gouncil, in 2011, decided that Mallkins Bank Golf Goumse was eontaminated land. However, the Council simultaneously issued a remediation

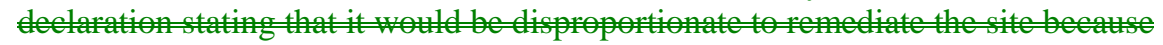

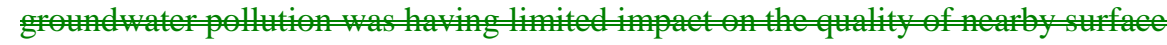
waters.

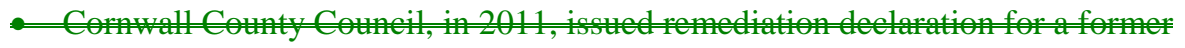
gasworks site where pollutants were entering the Fal Estuary through the habour wall.

Miller Homes Limited was fined $£ 100,000$ in 2016 over a pollution incident relating to a housing development in Huddersfield. The company admitted one environmental offence for an unauthorised discharge of water, containing silt and sediment, from the construction site into a nearby watercourse. The prosecuting Environment Agency told the court that the polluted water should have been managed on the construction site and that the company did not have permission to discharge silt water from the site (Environment Agency, 2016).

In 2017, Harron Homes Limited was fined £120,000 for illegally polluting a watercourse from a Huddersfield construction site. Mark West, environment management team leader at the Environment Agency, said "These pollution incidents had a significant impact on the water environment over a number of weeks, and were entirely avoidable. Construction companies should consider the potential environmental impact of developments they undertake at the initial planning stage and must adhere to environmental permitting rules and invest in appropriate management systems to prevent their activities from affecting the local environment" (Environment Agency, 2017a).

Thames Water Utilities Ltd (Thames Water) in 2017 was fined over £20 million for a series of significant pollution incidents on the River Thames. His Honour Judge Sheridan, condemned the "disgraceful conduct" of Thames Water, which he said was "entirely foreseeable and preventable" (Environment Agency, 2017b). He applied the Sentencing Council's Environmental Offences Definitive Guideline by utilising Thames Water's

${ }^{13}$ Water Resources Act (1991), C.57. 
turnover as the initial benchmark for setting the fine, as well as what he saw as its level of culpability and the degree of harm caused (Kennedys, 2017).

The Environment Agency (2018) complains that there are still far too many serious water pollution incidents with 317 occurring in 2016. It also notes (p.7) regarding the status and trends of chemicals in rivers and groundwater that "Some substances are already widespread in the environment as a result of past use that has contaminated land and sediment."As detailed in section 2, many of the contaminated land cases and remediation declarations have concerned water pollution.

The development of brownfield land risks such the commission of offences as regulation 38 of the EPR may be contravened and pollutants may already be present in the ground which may be released into controlled water by construction operations.

\subsection{Environmental Impact Assessment}

Environmental Impact Assessments (EIAs) are-were mandated for some developments by the 2011 EIA Directive ${ }^{14}$. Department for Communities and Local Government (2014) guidance explains that "The aim of EIA is to protect the environment by ensuring that a local planning authority when deciding whether to grant planning permission for a project, which is likely to have significant effects on the environment, does so in the full knowledge of the likely significant effects, and takes this into account in the decision making process."

Glasson, Therivel and Chadwick (2012) explained that EIA is a process that examines the environmental consequences of development in advance. There are five main steps: screening; scoping; preparing an environmental statement; making a planning application and consultation and finally decision making. In $R$ (Bateman) $v$ South Cambridgeshire District Council $^{15}$, the Court of Appeal gave important guidance on the need for sufficiently clear reasons to be given for a local authority's decision on a screening opinion that an environmental impact assessment is not required.

Changes to the 2011 EIA Directive are detailed in a subsequent Directive ${ }^{16}$ which was required to be implemented by 16 May 2017 (Holmes, 2016). The Town and Country Planning (Environmental Impact Assessment) Regulations $2017^{17}$ which apply to England are now in force. Arabadjieva (2016) considered that the 2014 Directive is a significant evolutionary (though perhaps not revolutionary) step in the development of the EIA regime which is now a more detailed, structured and sophisticated instrument. Thus, the development of brownfield sites may require expensive environmental impact assessments.

\section{The Political Agenda}

\footnotetext{
| ${ }^{14}$ GouncilDirective (EC)(2011), "92 on the assessment of the effects of certain public and private projects on the environment".

${ }^{15} R$ (Bateman) v South Cambridgeshire District Council [2011] EWCA Civ 157.

${ }^{16}$ Gouncil-Directive (EC)(2014) 2014 “52 amending Directive 2011/92/EU on the assessment of the effects of certain public and private projects on the environment Text with EEA relevance”.

${ }^{17}$ Town and Country Planning (Environmental Impact Assessment) Regulations 2017, SI2017/571.
}

Formatted: Normal

Formatted: Font: (Default) Times New Roman

Formatted: Font: (Default) Times New Roman 
This section examines the political agenda including priorities within the United Kingdom's West Midlands, the implications of Brexit, better regulation and the priority of reform of environmental law.

\subsection{West Midlands priorities}

Housing and brownfield sites are a political priority in the West Midlands; as evidenced by the Reeves (2017) booklet produced in accordance with The Combined Authorities (Mayoral Elections) Order 2017. The following statements were made by the mayoral candidates:

- "It's a plan to make sure we get the right level of housing that's needed, without concreting over green spaces" (Andy Street, Conservative).

- "Housing - I will ... incentivise the use of brownfield sites \& protect greenbelt" (Pete Durnell, UKIP).

- "Double the number of affordable new homes - and end the Tory scandal of homelessness, backed by a £500 million fund to clean up derelict sites” (Sion Simon, Labour).

The Conservative candidate, Andy Street, was elected as the first mayor of the West Midlands Combined Authority on 4 May 2017. Details of his housing plan are eagerly awaited.

\subsection{Brexit implications}

The result of the United Kingdom's (UK) European Union (EU) membership referendum of 23 June 2016 was 51.9\% of voters in favour of leaving the EU (Pocklington, 2016). The European Union (Notification of Withdrawal) Act $2017^{18}$ received royal assent on $16 \mathrm{March}$ 2017. As a consequence, the UK government initiated the official EU withdrawal process on 29 March 2017 by serving notice under Article 50 of the Treaty on European Union (2007). Most environmental law in England originates from the EU (Kellett, 2016 and Pocklington, 2016). However, the contaminated land regime does not derive from the EU.

The European Union (Withdrawal) Bill 2017-19 ${ }^{19}$ which is to repeal the European Communities Act $1972^{20}$ and make other provision in connection with the withdrawal of the United Kingdom from the EU is being debated. Lee (2017) emphasises the importance of continuing to hold the government to account for the implementation of environmental standards once the UK has left the EU. She focuses on three current EU accountability mechanisms: Commission-plus-Court of Justice enforcement mechanisms and fines, transparency and political accountability and EU legal principles that make domestic judicial review more compelling. She advocates a new body to scrutinise government environmental plans, reports and activities.

\subsection{Better regulation}

Kellett (2016) (Director of Legal Services for the Environment Agency for England) outlined governments' progress towards better regulation. The Coalition Government's 2014 Regulators' Code perpetuated the requirement that regulators perform their duties in a

\footnotetext{
${ }^{18}$ European Union (Notification of Withdrawal) Act 2017, c.9.

${ }^{19}$ The European Union (Withdrawal) HC Bill 2017-19

${ }^{20}$ European Communities Act 1972, c.68
}

Formatted: Font: (Default) Times New Roman

Formatted: Font: (Default) Times New Roman

Formatted: Font: (Default) Times New Roman

Formatted: Font: (Default) Times New Roman

Formatted: Font: (Default) Times New Roman 
business-friendly way. Furthermore, Section 108 of the Deregulation Act $2015^{21}$ mandates regulators to have regard to the desirability of promoting economic growth so undertaking only necessary and proportionate regulatory action. A systematic review of existing legislation is proposed but this demands resources to generate the benefit of less regulation.

The Coalition Government's red tape challenge review of environmental law resulted in proposals to "abolish 67 regulations, recast and improve 151 rules and uphold a number of other environmental laws" (Kellet, 2016, p. 203). The most significant impact (saving £8.7 million per year) was a new system of electronic waste transfer notes. Fogleman (2014a) advocated transferring implementation and enforcement of Part 2A of the EPA 1990 to the Environment Agency and imposing modified joint and several liability as the default for all persons who caused or knowingly permitted contaminated land.

The Housing and Planning Act $2016^{22}$ contains provisions to grant automatic planning permission in principle on brownfield sites identified on statutory registers but secondary legislation and statutory guidance is essential for implementation. The previous government's regulatory priorities in England were deregulation and simplification. There many initiatives to improve regulation but their impact merits analysis.

\subsection{Priority of environmental law reform}

The future direction of environmental policy and law in a non-EU UK will be determined by new trading agreements, international treaty obligations and national governments and administrations (Holmes, 2016). In particular, the extent to which current EU environmental laws will continue to apply to the UK is subject to review. "The sheer scale of environmental law within the UK and its reliance on EU law would make a law-by-law assessment of changes a significant and time-consuming task" (Holmes, 2016, p. 39). Nevertheless, Brexit will allow UK jurisdictions the freedom to develop their own agendas.

Voluntary agreements could be developed but Deanesly et al. (2016) highlighted that such an agreement on the increased use of secondary aggregates failed resulting in the introduction of the Aggregates Levy. The benefits of the remediation of brownfield sites for housing seem to be a political priority but reform of challenging environmental law issues less so.

Understandably, the legal complexities of Brexit will take precedence.

\section{Research Methodology}

\subsection{Methodology}

Fawcett and Pockett (2015, p.9) advocated that "all research has to have a clear purpose and involves politics at all levels" and "much research in the social field is orientated towards bringing about change." As outlined in the introduction, there is a national political focus on developing housing on brownfield land.

The study began with a literature review which is defined by Fink (2014, p. 3) as " $a$ systematic, explicit, and reproducible method for identifying, evaluating and synthesizing the existing body of completed and recorded work produced by researchers, scholars and

\footnotetext{
${ }^{21}$ Deregulation Act (2015), c.20, s.108.

${ }^{22}$ Housing and Planning Act (2016), c.22.
} 
practitioners." The objectives of the literature review were to describe the current knowledge of environmental law issues relevant to the regeneration of brownfield land and evaluate evidence that further research is "needed and significant" (Fink, 2014, p.191). The literature review identified the need to research the experience of brownfield environmental law challenges and recommended changes to environmental law from industry, legal experts and academia.

An inductive approach and an interpretivist epistemology with a phenomenological focus were chosen (Bryman, 2016). A constructionist ontological stance was adopted (Silverman, 2013). A qualitative paradigm was selected (Braun and Clarke, 2013) to explore the issues (Creswell, 2013).

The focus group approach was chosen because "the discussions occurring within focus groups will provide rich data on the group meanings associated with a given issue" and the "convenience and accessibility" (Bloor et al., 2001, p.7-8). Considering ethical issues, all participants were notified in advance that there would be a focus group, involvement was voluntary and their contributions anonymous (Silverman, 2013).

The attendees were randomly divided into three concurrent focus groups each facilitated by an academic and recorded by a PhD researcher. Hepburn and Bolden (2017) identified that transcription is often a prerequisite for qualitative research but it is time-consuming. The $\mathrm{PhD}$ researcher transcribers were therefore asked to summarise the discussion and identify key quotes and themes (Braun and Clarke, 2013). The transcripts were then reviewed by the author and, if required, amended. The transcripts were then collated and analysed by the author (Bryman, 2016) and conclusions abstracted.

\subsection{Aim and objectives}

The aim of the project was to investigate environmental law issues surrounding the regeneration and re-use of brownfield land. The objectives were:

- A critique of the literature on relevant environmental law issues including contaminated land, waste management, water pollution, environmental impact assessment issues and the political agenda.

- Delivering a collaborative forum between industry, legal experts and academic stakeholders on brownfield site environmental law challenges incorporating a focus group

- Data analysis and conclusions.

\subsection{Brownfield Research and Innovation (BRIC)}

The UK Government has demonstrated its commitment to making the Midlands a powerful engine for economic growth with the launch of its Midlands Engine Strategy and plan to invest $£ 392$ million across the Midlands through the Local Growth Fund. Some $£ 12$ million is to develop the Black County Garden City offering new locations for high quality housing development as "increasing housing supply is central to the government's vision of a country that works for everyone." In addition, "The Homes and Communities Agency will therefore work with Midlands Engine partners to develop a clear, prioritised schedule of publically owned sites for redevelopment” Department for Communities and Local Government (2017, p. 26-27). 
The response to the Midlands Engine Strategy (Midlands Engine, 2017, p.34) aims to unlock housing growth enabling the building of at least 600,000 new homes within 15 years. "The West Midlands Combined Authority ... and other designated growth areas all have track records of using innovative delivery vehicles to tackle the challenges of redeveloping their brownfield sites, which often have significant contamination, and of delivering housing growth in slower markets."

The University of Wolverhampton's School of Architecture and Built Environment founded the Brownfield Research and Innovation Centre (BRIC) in 2016. BRIC comprises over 50 members including representatives from housing associations, local authorities, the Environment Agency, consultants, contractors, specialist interest groups, financiers and academia.

BRIC's concern is the West Midlands region and national challenges surrounding the regeneration and re-use of brownfield and contaminated land. It aspires to become a centre for best practice and an information hub for brownfield related matters. A focus is to inform UK policy and assist stakeholders in meeting regional and national targets associated with the UK housing market. It is envisaged that BRIC will contribute to long-term plans for urban regeneration in the West Midlands.

\subsection{BRIC Environmental Law Challenges Forum}

The newly appointed Head of School of Architecture and the Built Environment (ABE) invited bids from a research fund. The author was successful and awarded funding for a Brownfield Research and Innovation (BRIC) - Environmental Law Challenges Forum at the University of Wolverhampton. BRIC members, former and current MSc Construction Law and Dispute Resolution students and $\mathrm{ABE}$ academics and $\mathrm{PhD}$ researchers were invited to the Forum which was held on 20 June 2017 with over 20 attendees.

The speakers and their topics were:

- Introduction: Head of the Built Environment.

- The Context: Brownfield Land and Environmental Research Analyst, Black Country Consortium. The speaker covered the regional context, BRIC and the Black Country LEP including its strategic projects.

- Risk Allocation: Head of Environmental Law, a Global 100 legal practice who focused on contaminated land.

- The Potential Penalties: Partner, the same Global 100 legal practice. The presenter outlined environmental offences, sentencing guidelines and civil sanctions, civil claims and risk management.

- The Research Perspective: this paper's author explained the findings of this paper's literature review and set the focus group questions.

\subsection{BRIC Environmental Law Challenges Focus Groups}

The three concurrent focus groups were invited to respond to two questions:

1. What is your experience of brownfield environmental law challenges?

2. What changes to environmental law would you recommend? 
The focus groups had the advantage of BRIC members being a pre-existing group with a demonstrable interest in the regeneration and re-use of brownfield and contaminated land supplemented by legal experts and academics.

\section{Focus Group Results}

6.1The focus group results are reported under the themes of contaminated land, waste management, regulators and legislation.

\subsubsection{Contaminated Land}

One contributor advocated that it was important that contaminated land is identified and cleaned-up but acknowledged the issue requires proper funding and resources. He continued that "It is also important for the Environment Agency officers to spend enough time with the bad companies."

Another participant complained about the lack of precision in terminology for example, "contaminated land should be distinctive from land contamination". He explained "I think local authorities have been a little bit hesitant in determining contaminated land" as this causes blight. He argued that is important for the planners to clarify the end use of the site "for example, here I am sitting on my industrial chemical factory and .. contaminants are not escaping .. it is under a car park so who cares." However, he continued that sometimes it is easier to develop brownfield rather than greenfield land because it is often well connected with roads and utilities, is not on a floodplain and has no geological issues.

A contributor contended that "surely there has got to be more of an incentive for a developer to take on these sites." Another participant replied "funding is probably the easiest option. A change in the law or relaxing the law is tricky but would have more effect." The contributor responded "for me, as a land buyer, it is all about certainty." He clarified that he needed to know the prospects of receiving a grant. He continued that sometimes "by the time you have stacked out its full costs, there is no value." He concluded "for me, contaminated land, don't go near it!"

Concern was expressed that "brownfield land site owners are holding out for too much money for these sites" because of the availability of grants. However, a participant clarified that "ultimately, when you look at the amount that is legitimately available, grants are not there to prop up land values." A participant argued "there is an enormous pot of money available if you can get round the State Aid issues."

Regarding housing provision, a contributor stated "there are housing developers who specialise with working within less prosperous areas but, you are not getting a high quality product or one that fits easily with the Garden City concept in the Black Country. You've got a square to round off somehow in terms of quality and viability." He continued that there is demand for cost-effective housing, particularly social housing, in this area.

A contributor explained that best practice can encourage the use and development of brownfield sites. He gave the example of an Environment Unit under Scottish Enterprise that compiled a 150 page report on an investigated brownfield site. As a consequence, a major USA company became interested in purchasing the site. He advocated that advance investigations can be employed to market such land. He concluded "I am not sure if these 
techniques are still happening in the industry, the best thing we can be is a facilitation organization (ie. become information providers on a particular site.)"

A participant asserted that the use of bioremediation is very important in cleaning contaminated land instead of excavating, removing and refilling sites. "this is too good to be true, but it does actually work."

A contributor contended that clients expect inexpensive site investigations. However, he asserted that "data is always important in assessing contaminated land, the smaller the amount of data on a site, the higher the risk." Moreover, he explained that a smart consultant may report "due to the nature of the site and contaminants, by the time it reaches the receptor, the concentration will be reduced and will not cause harm."

A participant concluded "buyer beware if you are buying a site.... First of all are you paying the right price for it based on the possible associated issues and making sure that you undertake due diligence."

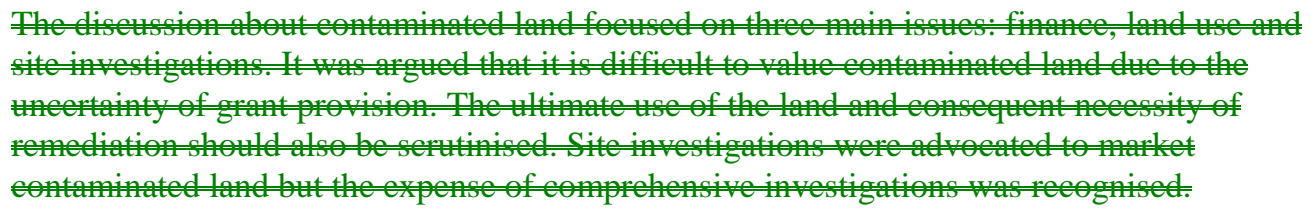

\subsubsection{Waste Management}

A participant explained that usually contaminated materials must go to a licensed landfill in order to comply with the Regulations. He continued that as landfill tax is payable at £86 per tonne, some people cheat the system because of the cost resulting in illegal disposal of waste. He argued "the system is leaking, it's not airtight". He complained that contractors break the rules because the risk of being caught is slight and profit exceeds the fines so they can charge a cheaper rate. He objected to this practice forcing some compliant companies out of business.

He contended that regulators (especially the Environment Agency) do not have enough manpower and tougher laws could be introduced. One contributor related that the Environment Agency's West Midlands Area Manager’s biggest concern was waste crime. comp ond non mom and endorsed by the reported view of the Environment Ageney's West Midlands Area Mancere

\subsubsection{RegulatorsRegulators.}

A participant criticized regulators "I think that all regulators have traditionally just had the mind set of being a policeman with a clipboard. Now I am going to tick my boxes." However, he did concede that "they are under resourced and under staffed but they ought to be helping people get better." However, he justified their stance "their concern is because they have given the advice ... they can't prosecute against that advice."

A contributor reported that the Environment Agency now has a range of enforcement options in addition to prosecution. For example, civil sanctions of a promise to fix the problem and making a donation to a local wildlife charity instead of paying a fine to the Government. He 
explained that the Environment Agency and the Health and Safety Executive were under pressure to modernise.

Controversially, one participant suggested that perhaps if the Environment Agency shared the profit and losses with a developer, they would be more helpful rather than focusing on enforcement, deterrence and fines. The role of regulators was scrutinized. Regulators' traditional policing role was described but their more modern enforcement options recognised. A contentious suggestion was made that the Environment Agency should operate as a commercial institution.

\subsection{4_Legislation}

A participant explained that most environmental laws in the EU originated from the UK for example, the permitting regime. He continued that most environmental legislation in the UK concerned ecology. He described the Severn Estuary barrage which could supply $10 \%$ of the UK's energy needs but has not been approved due to environmental, in particular wildlife, law. He protested that this was despite a plan to rehouse organisms before construction.

A contributor argued that all European legislation should be simplified "it is cold towel on your head time ... it is bad enough for a lawyer." He explained that regarding Brexit "to begin with they will incorporate everything into our law but we would then have an opportunity to adapt law to suit ourselves... I don't know if there will be much political will to dilute the measures in place to protect the environment. There will be other priorities for example, trade." He continued "we do have environmental protection measures which, while they are probably excessively bureaucratic, are there for a reason. They stop really serious criminal behaviour. They are not going to start again with a blank sheet of paper.”

"I am not in agreement with all that, construction projects worth millions held up by one or two little newts or a couple of bats" one contributor protested. He maintained that environmental law protection for animals should be diluted. A participant responded "I can see the frustration but also the need for environmental protection to be there." Nevertheless, he conceded that the law is disproportionate.

A contributor explained "State Aid is such a key and difficult issue for dealing with contamination ... you have to look at any uplift in land value from the grant available”. He continued that the public sector can very easily obtain grants whereas "the private sector trying to obtain grants often faces challenges with value issues and what is the ultimate use of this site." He advocated that BRIC, with its links to Government, try to promote a different scheme.

A compulsory purchase scheme was advocated. However, one contributor explained "putting a compulsory purchase scheme in place is a costly process. Particularly if you have a landowner that is not prepared to sell easily. You pay potentially $10 \%$ over the cost of the site." Nevertheless, a participant suggested "perhaps regions can bring in new laws ... we are going to identify sites that we want to develop under something similar to compulsory purchase. We will set the price."

Environmental and European legislation were criticised but their importance recognised. The proportionality of environmental legislation was debated. New State Aid and compulsory purchase schemes were advocated.

Formatted: Font: (Default) Times New Roman, 12 pt 
6.6_-Summary

Gontaminated land, waste management, regulators and legislation were discussed. The participants contributed their experiences and proposed changes to environmental law on these topics. However, water pollution and environmental impact assessments were not eonsidered.

\section{Focus Group Analysis,}

The discussion about contaminated land focused on three main issues: finance, land use and site investigations. It was argued that it is difficult to value contaminated land due to the uncertainty of grant provision. The ultimate use of the land and consequent necessity of remediation should also be scrutinised. The importance of bioremediation rather than excavating, removing and refilling sites was emphasised. The advantages of developing brownfield because it is often well connected with roads and utilities, is not on a floodplain and has no geological issues rather than greenfield land were advocated. Site investigations were advocated to market contaminated land but the expense of comprehensive investigations was recognised.

Contempt of and non-compliance with waste disposal regulations was identified as a concern and endorsed by the reported view of the Environment Agency's West Midlands Area Manager. Greater resource and tougher legislation were advocated to combat waste crime.

The role of regulators was scrutinized. Regulators' traditional policing role was described but their more modern enforcement options recognised. A contentious suggestion was made that the Environment Agency should operate as a commercial institution.

Environmental and European legislation were criticised but their importance recognised. The implementation of environmental law after Brexit was considered. The proportionality of environmental legislation was debated. New State Aid and compulsory purchase schemes were advocated.

Contaminated land, waste management, regulators and legislation were discussed. The participants contributed their experiences and proposed changes to environmental law on these topics. However, water pollution and environmental impact assessments were not considered.

\subsection{Conclusions}

In this section, conclusions are reached for industry and academia.

\subsubsection{Industry}

There is a national political focus on developing housing on brownfield land. However, developers face many environmental law challenges when endeavouring to progress housing on brownfield sites including contaminated land, funding, waste treatment permits, water pollution and environmental impact assessments. Therefore, a greater industry appreciation of environmental law should be encouraged.

Developers may be discouraged from developing contaminated land due to the risk of introducing pathways and receptors during construction. Local authorities are also concerned
Formatted: Normal, No bullets or

numbering

Formatted: List Paragraph, Outline numbered + Level: $1+$ Numbering Style: 1, 2, 3, .. + Start at: $1+$ Alignment: Left + Aligned at: $0.63 \mathrm{~cm}$ + Indent at: $1.27 \mathrm{~cm}$

Formatted: Font: (Default) Times New Roman, 12 pt, Bold 
about the expense of possible appeals to remediation notices including legal fees and funding the remediation costs themselves.

A developer who purchases brownfield land runs the risk of the local authority subsequently serving a remediation notice on them. Their potential liability is uncapped and failure to comply could result in criminal conviction. Case law demonstrates that developers have been served remediation notices.

Potential sources of public sector funds have been identified but access to them is complex. A key issue is that remediation costs can exceed the current market value of the land.

The group discussion on contaminated land focused on three main issues: finance, land use and site investigations. It was argued that it is difficult to value contaminated land due to the uncertainty of grant provision. The ultimate use of the land and consequent necessity of remediation should also be scrutinised. Site investigations were advocated to market contaminated land but the expense of comprehensive investigations was recognised.

Construction operations on brownfield sites may require a waste treatment permit. Contempt of and non-compliance with waste disposal regulations was identified as a concern in the focus groups and endorsed by the reported views of the West Midlands Area Manager of the Environment Agency.

The development of brownfield land risks water pollution offences as-and contaminants may already be present in the ground which may be released into controlled water by construction operations. Development of brownfield sites may also require expensive environmental impact assessments.

\subsubsection{Academia}

There are many topics which merit future research. Most of environmental law applying in England and Wales derives from Europe so the opportunity to revise this area of law has arisen. Environmental and European legislation was criticised in the focus groups but their importance recognised. The proportionality of environmental legislation was debated. New State Aid and compulsory purchase schemes were advocated.

Researchers have argued that Part 2A of the EPA 1990 is unfit for purpose. In the UK, as a priority, the polluter should pay, but where the polluter is not found, it may be possible for residual liability to rest elsewhere on, for example, owners or occupiers of the land or the State. However, an opportunity has arisen to evaluate this choice and perhaps consider a different framework.

| There are many initiatives to improve regulation but their impact merits analysis. The role of regulators came under scrutiny in the focus groups. Regulators' traditional policing role was described but their more modern enforcement options recognised. A contentious suggestion was made that the Environment Agency should was operate commercially.

The benefits of the remediation of brownfield sites for housing seem to be a political priority but reform of challenging environmental law issues less so. Understandably, the legal complexities of Brexit will take precedence. 


\section{References}

Arabadjieva, K. (2016) Better Regulation In Environmental Impact Assessment: The Amended EIA Directive. Journal of Environmental Law, 8 (1), pp.159-168.

Bloor, M., Frankland, J., Thomas, M. and Robson, K. (2001) Focus Groups in Social Research, Sage, London. Braun, V. and Clarke, V. (2013) Successful Qualitative Research, Sage, London.

Brown, L. (2016) The contaminated land regime and austerity. International Journal of Law in the Built Environment, 28 (3), pp.210-225.

Bryman, A. (2016), Social Research Methods, $5^{\text {th }}$ ed., Oxford University Press, Oxford.

Campaign to Protect Rural England (2016) More than a million homes possible on suitable brownfield land [Online]. [Accessed 22 May 2017]. Available at: < http://www.cpre.org.uk/media-centre/latest-newsreleases/item/4414-more-than-a-million-homes-possible-on-suitable-brownfieldland?highlight=WyJicm93bmZpZWxkIiwiJ2Jyb3duZmllbGQnIiwiJ2Jyb3duZmllbGQiLCJzaXRlcyIsInNp dGVzJyIsInNpdGVzJywiLCJicm93bmZpZWxkIHNpdGVzIl0=>.

Chancellor (2016) Autumn Statement 2016: Some of the things we have announced [Online]. [Accessed 22 May 2017]. Available at: < https://www.gov.uk/government/news/autumn-statement-2016-some-of-the-thingsweve-announced $>$.

Creswell, J. (2013), Qualitative Inquiry \& Research Design, $3^{\text {rd }}$ ed., Sage, California.

Deanesly, C., Evers, A., Mitchener, R., Potter, A. and Stone, H.(2016) Implications of the UK leaving the European Union: Waste Management: Strategic Issues - England and Wales. Environmental Law and Management, 8 (3), pp.42-45.

Department for Communities and Local Government (2014) Guidance: Environmental Impact Assessment. London: Department for Communities and Local Government.

Department for Communities and Local Government (2015) Building more homes on brownfield land: Consultation proposals. London: Department for Communities and Local Government.

Department for Communities and Local Government (2017) Midlands Engine Strategy. London: Department for Communities and Local Government.

Department for Environment Food and Rural Affairs (2017) Water Resources Act [online]. [Accessed $24 \mathrm{May}$ 2017]. Available at:<-http://adlib.everysite.co.uk/adlib/defra/content.aspx?doc=18800\&id-18802>.

Environment Agency (2016), "Housing development firm fined £100,000 over construction site pollution" available at https://www.gov.uk/government/news/housing-development-firm-fined-100000-overconstruction-site-pollution (accessed 1 March 2018)

Environment Agency (2017a) "Harron Homes fined £120,000 over construction pollution” available at: https://www.gov.uk/government/news/harron-homes-fined-120000-over-construction-pollution (accessed 1 March 2018)

Environment Agency (2017b), “Thames Water ordered to pay record £20 million for river pollution” available at: https://www.gov.uk/government/news/thames-water-ordered-to-pay-record-20-million-for-riverpollution (accessed 17 November 2017).

Environment Agency (2018), “The State of the Environment: Water Quality” available at: https://www.gov.uk/government/uploads/system/uploads/attachment data/file/682223/State of the enviro nment_water_quality_report_2016.pdf (accessed 21 February 2018)

EUR-Lex (2016), “ The polluter-pays principle and environmental liability” available at: http://eurlex.europa.eu/legal-content/EN/TXT/?uri=LEGISSUM\%3Al28120 (accessed 6 March 2018)

Fawcett, B. and Pockett, R. (2015), Turning Ideas into Research, Sage, London.

Fink, A. (2014), Conducting Research Literature Review, $4^{\text {th }}$ ed., Sage, Los Angeles.

Fogleman, V. (2014a) The contaminated land regime: time for a regime that is fit for purpose (Part 2). International Journal of Law in the Built Environment, 6 (2), pp.129-151.

Fogleman, V. (2014b) The contaminated land regime: time for a regime that is fit for purpose (Part 1). International Journal of Law in the Built Environment, 6 (2), pp.43-68.

Glasson, J., Therivel, R. and Chadwick, A. (2012) Introduction to Environmental Impact Assessment. $4^{\text {th }}$ ed. London:Routledge.

Hepburn, A. and Bolden, G. (2017) Transcribing for Social Research, Sage, London.

Holmes, S. (2016) Brexit and environmental law: Strategic Issues - England and Wales. Environmental Law and Management, 28 (1), pp.37-41.

Housing and Planning Minister (2017) New measures to unlock brownfield land for thousands of homes [Online]. [Accessed 22 May 2017]. Available at: < https://www.gov.uk/government/news/new-measuresto-unlock-brownfield-land-for-thousands-of-home $>$.

Kellett, P. (2016) Better regulation, deregulation and environmental law. Environmental Law and Management, 27 (5), pp.200-207. 
Kennedys (2017), "When it rains it pours: Thames Water hit with record fine" available at: http://www.kennedyslaw.com/article/when-it-rains-it-pours-thames-water-hit-with-record-fine (accessed 20 February 2018)

Lees, E. (2016) The polluter pays principle and the remediation of land. International Journal of Law in the Built Environment, 8 (1), pp.2-20.

Lee, M. (2017) Accountability for Environmental Standards after Brexit. Environmental Law Review, 19 (2), pp.89

Lowther, J. (2006) The appropriate person for remediation: successor liability for contaminated land. Environmental Law and Management, 18 (3), pp.131-135.

Midlands Engine (2017) The Midlands Engine Vision for Growth: a response to the Government's Midlands Engine Strategy for Growth Midlands: Midlands Engine.

Pocklington, D. (2016) Brexit, Article 50 and the future. Environmental Law and Management, 28 (2), pp.102107

Reeves, M. (2017) Election of Mayor for the West Midlands Combined Authority. Combined Authority Returning Officer for the West Midlands. 4 May 2017

Silverman, D. (2013), Doing Qualitative Research, $4^{\text {th }}$ ed., Sage, London

Wong, C. and Schulze-Baing A. (2010) Brownfield residential redevelopment in England What happens to the most deprived neighbourhoods? York: Joseph Rowntree Foundation 